\title{
HUBUNGAN AKTIVITAS BELAJAR MANDIRI DENGAN HASIL BELAJAR RANGKAIAN LISTRIK
}

\author{
${ }^{1}$ Cintya Trikirana, ${ }^{2}$ Soeprijanto, ${ }^{3}$ Faried Wadjdi \\ ${ }^{1,2,3}$ Pendidikan Teknik ElektroTeknik Elektro, Universitas Negeri Jakarta
}

\begin{abstract}
This research aims to knowing description data of individual learning activities and determine whether there is a positive and significant relationship between individual learning activities with learning outcomes of Electrical Circuit. This research was conducted at SMKN 26 Jakarta. The method used is survey method with correlational approach.

Data collection of dependent variables using the test of learning outcomes. The population in this study were students of class X TIPTL which amounted to 60 students. The sampling technique using simple random sampling. The sample of this research are 51 students. The collected data will be processed by hypothesis test, correlation coefficient test and coefficient of determination test after the data fulfill the normal and linier requirements. The results showed that the average of individual learning activities is 94.35 it means individual learning activities of students of class X SMKN 26 Jakarta entered into enough category of individual learning activities, the detail frecquency of each individual learning activities category as follows: Students who entered very high category of individual learning activities is $19.60 \%$. High category of individual learning activities is $25.49 \%$. Low category of individual learning activities that is $15.69 \%$. The most students included into enough category of individual learning activities is $35.29 \%$ and at least into very low category of individual learning activities is $3.92 \%$. The result of this research is $t_{\text {count }}>t_{\text {table }}(7.89>2.01)$ and correlation coefficient value 0.748 , this result showed that there is positive and significant correlation between individual learning activities with learning outcomes of Electrical Circuit.
\end{abstract}

Keywords: Individual learning activities, Learning Outcomes

\begin{abstract}
Abstrak
Penelitian ini bertujuan untuk mengetahui gambaran aktivitas belajar mandiri siswa dan mengetahui apakah terdapat hubungan yang positif dan signifikan antara aktivitas belajar mandiri dengan hasil belajar mata pelajaran Rangkaian Listrik. Penelitian ini dilakukan di SMK Negeri 26 Jakarta. Metode yang digunakan adalah metode survey.

Pengumpulan data variabel terikat menggunakan tes hasil belajar dan pengumpulan data variabel bebas menggunakan kuesioner. Populasi dalam penelitian ini adalah siswa kelas X TIPTL yang berjumlah 60 siswa. Teknik pengambilan sampel menggunakan simple random sampling. Sampel penelitian berjumlah 51 siswa. Hasil penelitian menunjukkan bahwa nilai rata rata aktivitas belajar mandiri siswa yaitu 94,35 sehingga aktivitas belajar mandiri siswa kelas X SMK Negeri 26 Jakarta masuk ke dalam kategori aktivitas belajar mandiri cukup tinggi. Hasil penelitian menunjukkan bahwa nilai rata rata hasil belajar Rangkaian Listrik yaitu 83,94 sehingga hasil belajar Rangkaian Listrik masuk ke dalam kategori tinggi. Hasil penelitian diperoleh nilai $t_{\text {hitung }}>t_{\text {tabel }}(7,89>2,01)$ dan nilai koefisien korelasi sebesar 0,748, hasil ini menunjukan bahwa terdapat hubungan yang positif dan signifikan antara aktivitas belajar mandiri dengan hasil belajar Rangkaian Listrik.

Kata kunci: Aktivitas belajar mandiri, Hasil belajar
\end{abstract}

\section{PENDAHULUAN}

Proses belajar yang dialami siswa bukanlah sekedar menerima materi pelajaran yang diajarkan guru atau belajar hanya ketika mendapat pengawasan dari guru, tetapi dibutuhkan inisiatif dari dalam diri siswa itu sendiri untuk melakukan aktivitas belajar mandiri. Aktivitas belajar mandiri bukan semata mata belajar sendiri. Dalam pengertian sebenarnya, aktivitas belajar mandiri yaitu siswa tahu kapan harus memerlukan bantuan orang lain seperti berdiskusi dengan kelompok belajar atau bertanya kepada guru diluar jam pelajaran mengenai materi pelajaran yang belum dimengerti ketika belajar sendiri.
Siswa yang telah terbiasa melakukan aktivitas belajar mandiri akan memiliki inisiatif yang tinggi untuk belajar, baginya belajar merupakan hal yang menyenangkan, ia akan tetap belajar walaupun tidak sedang diawasi oleh guru. Siswa yang telah terbiasa untuk melakukan aktivitas belajar mandiri akan menunjukan kesiapannya dalam belajar, seperti aktif dalam bertanya, berdiskusi, mengemukakan pendapat, dan sebagainya. Sedangkan siswa yang tidak terbiasa melakukan aktivitas belajar mandiri akan cenderung pasif pada saat proses belajar.

Aktivitas belajar mandiri yang dilakukan siswa akan membuat siswa terlatih dan mempunyai kebiasaan melakukan tindakan yang baik, sehingga siswa yang 
sering melakukan aktivitas belajar mandiri akan mampu mencapai hasil belajar yang tinggi. Namun, pada kenyataannya tidak semua siswa rajin belajar, ada siswa yang belum memiliki inisiatif untuk belajar mandiri. Hal ini mengakibatkan hasil belajar yang diperoleh siswa bervariatif, ada siswa yang memperoleh hasil belajar yang tinggi dan ada pula siswa yang memperoleh hasil belajar yang rendah. Berdasarkan latar belakang di atas, diperoleh rumusan masalah sebagai berikut: 1) Bagaimana gambaran aktivitas belajar mandiri siswa?. 2) Apakah terdapat hubungan yang positif dan signifikan antara aktivitas belajar mandiri dengan hasil belajar siswa pada mata pelajaran Rangkaian Listrik ?

\section{METODE}

Metode penelitian merupakan cara ilmiah untuk mendapatkan data dengan tujuan dan kegunaan tertentu. Metode yang digunakan pada penelitian ini adalah metode survey dengan pendekatan korelasional.

\section{Populasi dan Sampel}

Pada penelitian ini, yang termasuk kedalam populasi adalah siswa kelas $\mathrm{X}$ kompetensi keahlian Teknik Instalasi Pemanfaatan Tenaga Listrik SMK Negeri 26 Jakarta angkatan 2016/2017 yang berjumlah 60 siswa.

Teknik yang dipakai untuk menentukan anggota sampel dalam penelitian ini adalah simple random sampling. Berdasarkan tabel Isaac dan Michael dengan taraf kesalahan 5\%, maka dengan jumlah populasi 60 siswa, maka diperoleh jumlah sampel sejumlah 51 siswa.

\section{Teknik Pengumpulan Data}

Teknik pengumpulan data yang dilakukan oleh peneliti untuk mengumpulkan data variabel bebas aktivitas belajar mandiri adalah dengan membagikan kuesioner berupa selembaran kepada subjek peneliti dan diisi saat itu juga dengan pengawasan peneliti. Untuk mengkonfimasi data aktivitas belajar mandiri yang diperoleh maka dilakukan wawancara kepada orang tua siswa.

\section{Instrumen Hasil Belajar}

Hasil belajar diperoleh melalui tes hasil belajar. Tes yang dilakukan berupa butir soal pilihan ganda dengan kategori point 1 untuk jawaban yang benar dan point 0 untuk jawaban yang salah. Instrumen Aktivitas Belajar Mandiri

Aktivitas belajar mandiri siswa diukur dari skor yang diperoleh melalui pengisian kuesioner berjumlah 43 soal dengan penilaian tiap soal sebagai berikut: skor 4 untuk jawaban sangat sering, skor 3 untuk jawaban sering, skor 2 untuk jawaban jarang, skor 1 untuk jawaban sangat jarang.

\section{Uji Validitas dan Reliabilitas Data}

Uji validitas untuk instrumen hasil belajar menggunakan rumus koefisien korelasi biserial $\left(\mathrm{r}_{\text {bis }}\right)$.Uji realibilitas untuk instrumen hasil belajar menggunakan rumus KR 20. Pengujian realibilitas dengan rumus KR 20.

Uji validitas untuk instrumen aktivitas belajar mandiri menggunakan rumus Pearson Product Moment. Uji reliabilitas untuk instrumen aktivitas belajar mandiri menggunakan rumus Alpha Crownbach.

\section{Uji Prasyarat Analisis Data \\ Persamaan Regresi}

Pada penelitian ini, persamaan regresi menggunakan rumus regresi linier sederhana. Regresi linier sederhana didasarkan pada hubungan fungsional satu variabel independen dengan satu variabel dependen. Menurut Sugiyono (2012:261), persamaan regresi linier sederhana adalah sebagai berikut: $\hat{Y}=a+b X$

\section{Uji Normalitas}

Uji normalitas bertujuan untuk melihat tingkat kenormalan data yang digunakan, apakah data berdistribusi normal atau tidak. Pada penelitian ini, uji normalitas menggunakan liliefors dengan taraf $\alpha=0,05$.

\section{Uji Linieritas}

Uji linieritas bertujuan untuk mengetahui apakah garis regresi antara $\mathrm{X}$ dan $\mathrm{Y}$ membentuk garis linier atau tidak.

Hipotesis Statistik:

$\mathrm{H}_{\mathrm{o}} \quad: \mathrm{Y}=\mathrm{a}+\beta \mathrm{X}$, regresi linear

$\mathrm{H}_{\mathrm{a}} \quad: \mathrm{Y} \neq \mathrm{a}+\beta \mathrm{X}$, regresi tidak linear

Kriteria pengujian:

Jika $F_{\text {hitung }}<\mathrm{F}_{\text {tabel}}$, maka $\mathrm{H}_{0}$ diterima dan regresi linear.

Jika $\mathrm{F}_{\text {hitung }}>\mathrm{Ft}_{\mathrm{abel}}$, maka $\mathrm{H}_{1}$ diterima dan regresi tidak linear.

\section{Uji Signifikansi Regresi}

Uji signifikansi regresi dilakukan untuk memperkirakan hubungan yang terjadi antara variabel $\mathrm{X}$ dan $\mathrm{Y}$.

Hipotesis:

$\mathrm{H}_{\mathrm{o}}$ : Model regresi tidak signifikan

$\mathrm{H}_{\mathrm{a}}$ : Model regresi signifikan 
Kriteria pengujian :

Jika $\mathrm{F}_{\text {hitung }}>\mathrm{F}_{\text {tabel }}$ maka $\mathrm{H}_{\mathrm{o}}$ ditolak, sehingga regresi dikatakan berarti (signifikan)

Jika $F_{\text {hitung }}<\mathrm{F}_{\text {tabel }}$ maka $\mathrm{H}_{\mathrm{o}}$ diterima, sehingga regresi dikatakan tidak berarti (tidak signifikan)

\section{Uji Hipotesis}

\section{Uji Koefisien Korelasi Product Moment}

Pengujian hipotesis penelitian dalam penelitian ini diuji menggunakan uji statistik product moment untuk melihat hubungan antara variabel $\mathrm{x}$ dan variabel y.

Hipotesis Statistik:

$H_{o}: \rho=0$ Tidak terdapat hubungan antara variabel $\mathrm{X}$ dengan variabel $\mathrm{Y}$

$H_{a}: \rho \neq 0$ Terdapat hubungan yang positif antara variabel $\mathrm{X}$ dengan variabel $\mathrm{Y}$

Kriteria pengujian :

1. Jika $\rho=0$, maka Ho diterima

2. Jika $\rho \neq 0$, maka Ho ditolak

\section{Signifikansi Korelasi}

Uji t digunakan untuk mengetahui pengaruh variabel independen terhadap variabel dependen, apakah pengaruhnya signifikan atau tidak.

Hipotesis Statistik :

Ho $: \rho=0$ tidak ada hubungan yang signifikan

Ha $: \rho \neq 0$ ada hubungan yang signifikan

Kriteria pengujian :

Jika t hitung < t tabel, maka ho diterima

Jika t hitung $>\mathrm{t}$ tabel, maka ho ditolak

\section{Uji Koefisien Determinasi}

Uji koefisien determinasi digunakan untuk menyatakan besar kecilnya sumbangan variabel $\mathrm{x}$ terhadap variabel y dengan menggunakan rumus koefisien determinasi sebagai berikut:

$\mathrm{kd}=\mathrm{r}_{\mathrm{xy}}{ }^{2} \mathrm{x} 100 \%$

keterangan:

$\mathrm{kd}=$ koefisien determinasi

$\mathrm{r}_{\mathrm{xy}}=$ tingkat keterkaitan hubungan

\section{HASIL DAN PEMBAHASAN}

\section{Hasil Belajar Rangkaian Listrik}

Data hasil belajar diperoleh melalui nilai mata pelajaran Rangkaian Listrik kelas X TIPTL SMK Negeri 26 Jakarta. Berdasarkan data yang terkumpul, diperoleh skor terendah sebesar 74 dan skor tertinggi sebesar 94 dengan jumlah skor 4281 sehingga rata-rata skor hasil belajar Rangkaian Listrik sebesar 83,94; varians $\left(\mathrm{S}^{2}\right)$ sebesar 28,26 dan simpangan baku (S) sebesar 5,32.
Distribusi frekuensi data hasil belajar Rangkaian Listrik dapat dilihat pada tabel 4.1 dengan rentang skor adalah 20, banyak kelas adalah 7 dan panjang interval adalah 3 . Lebih jelasnya, maka distribusi frekuensi hasil belajar Rangkaian Listrik digambarkan dalam histogram di bawah ini:

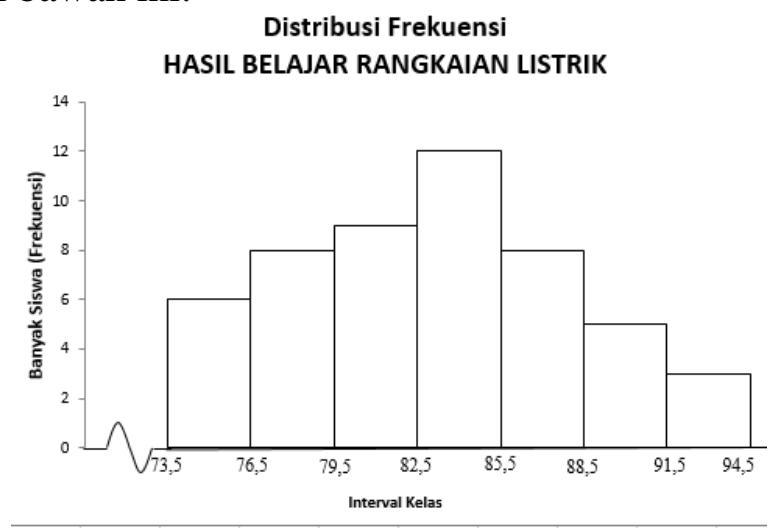

Gambar 1. Grafik Histogram Hasil Belajar Rangkaian Listrik

Berdasarkan pengategorian data hasil belajar, dengan nilai rata rata yang diperoleh yaitu 83,94, maka hasil belajar siswa kelas X SMKN 26 Jakarta masuk ke dalam kategori tinggi karena nilai rata rata > nilai Kriteria Ketuntasan Minimal atau 83,94 > 80. Rincian frekuensi nya adalah sebagai berikut: Siswa yang memperoleh nilai $>80$ yaitu $72,5 \%$ atau sekitar 37 siswa. Siswa yang memperoleh nilai < 80 yaitu $27,5 \%$ atau sekitar 14 siswa.

\section{Aktivitas Belajar Mandiri}

Data aktivitas belajar mandiri diperoleh melalui pengisian kuesioner dengan skala likert oleh 51 sampel. Berdasarkan data yang terkumpul, diperoleh skor terendah sebesar 58 dan skor tertinggi sebesar 132 dengan jumlah skor 4812 sehingga rata-rata skor aktivitas belajar mandiri sebesar 94,35; varians $\left(\mathrm{S}^{2}\right)$ sebesar 356,47 dan simpangan baku (S) 18,88.

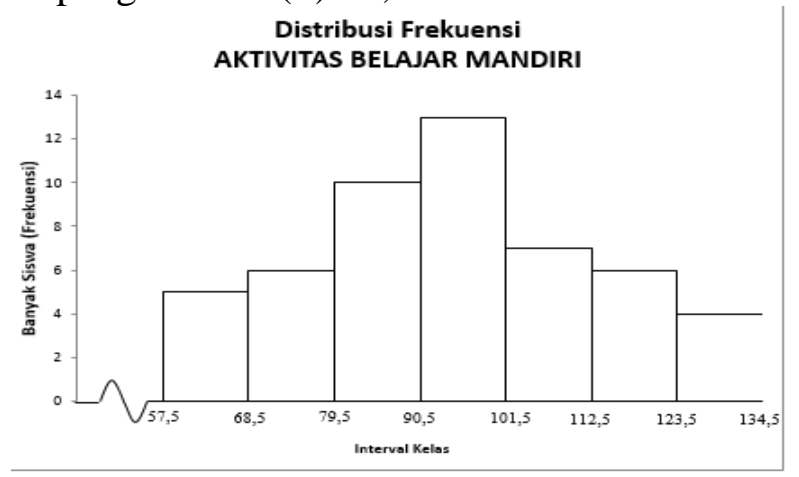

Gambar 2. Grafik Histogram Aktivitas Belajar Mandiri 
Distribusi frekuensi data aktivitas belajar mandiri dapat dilihat pada tabel 1. dengan rentang skor adalah 74, banyak kelas adalah 7 dan panjang interval adalah 11. Lebih jelasnya, maka distribusi frekuensi aktivitas belajar mandiri digambarkan dalam histogram di bawah ini:

Berdasarkan pengategorian data aktivitas belajar mandiri, dengan nilai rata rata yang diperoleh yaitu 94,35, maka aktivitas belajar mandiri siswa kelas X SMKN 26 Jakarta masuk ke dalam kategori cukup tinggi. Rincian frekuensi nya adalah sebagai berikut: siswa yang masuk dalam kategori aktivitas belajar mandiri rendah yaitu $15,69 \%$ atau sekitar 8 siswa. Siswa yang masuk dalam kategori aktivitas belajar mandiri sangat tinggi yaitu $19,60 \%$ atau sekitar 10 siswa. Siswa yang masuk dalam kategori aktivitas belajar mandiri tinggi yaitu 25,49\% atau sekitar 13 siswa. Frekuensi siswa tertinggi terdapat pada kategori aktivitas belajar mandiri cukup tinggi yaitu $35,29 \%$ atau sekitar 18 siswa dan frekuensi paling rendah terdapat pada kategori aktivitas belajar mandiri sangat rendah yaitu 3,92\% atau sekitar 2 siswa.

\section{Pengujian Persyaratan Analisis Data Persamaan Garis Regresi}

Analisis regresi linier sederhana terhadap pasangan data penelitian antara aktivitas belajar mandiri dengan hasil belajar Rangkaian Listrik menghasilkan koefisien arah regresi sebesar 0,21 dan konstanta sebesar 64,07. Bentuk hubungan antara aktivitas belajar mandiri dengan hasil belajar Rangkaian Listrik memiliki persamaan regresi $\hat{Y}=64,07+0,21 X$.

\section{Uji Normalitas}

Hasil perhitungan uji Liliefors variabel $\mathrm{Y}$ didapatkan $\mathrm{L}_{\text {hitung }}=0,111$ pada taraf signifikansi 0,05 dengan jumlah sampel 51, $\mathrm{L}_{\text {tabel }}=0,1241$. Hasil ini berarti $\mathrm{L}_{\text {hitung }}<\mathrm{L}_{\text {tabel, }}$, sehingga data variabel $\mathrm{Y}$ berdistribusi normal.

Hasil perhitungan uji Liliefors variabel $\mathrm{X}$ didapatkan $\mathrm{L}_{\text {hitung }}=0,0715$ pada taraf signifikansi 0,05 dengan jumlah sampel 51, $\mathrm{L}_{\text {tabel }}=0,1241$. Hasil ini berarti $\mathrm{L}_{\text {hitung }}<\mathrm{L}_{\text {tabel}}$, sehingga data variabel $\mathrm{X}$ berdistribusi normal.

\section{Uji Linieritas Regresi}

Hasil perhitungan menunjukkan $F_{\text {hitung }}<F_{\text {tabel }}$ $(0,34<1,96)$. Hasil ini berarti Ho diterima sehingga model regresi linier.

\section{Uji Signifikansi Regresi}

Berdasarkan hasil perhitungan $F_{\text {hitung }}$ sebesar 62,20 dan $F_{\text {tabel }}$ sebesar 4,04. Jadi, dalam pengujian ini dapat disimpulkan bahwa $\mathrm{F}_{\text {hitung }}>$ $F_{\text {tabel }}(62,20>4,04)$. Hasil ini berarti $\mathrm{H}_{\mathrm{o}}$ ditolak sehingga persamaan regresi adalah berarti atau signifikan.

\section{Pengujian Hipotesis \\ Uji Koefisien Korelasi}

Berdasarkan perhitungan product moment diperoleh $\mathrm{R}_{\mathrm{xy}}=0,748$, karena $\rho \neq 0$ dengan demikian dapat disimpulkan bahwa terdapat hubungan yang positif antara aktivitas belajar mandiri dengan hasil belajar Rangkaian Listrik. Nilai koefisien korelasi $\left(\mathrm{R}_{\mathrm{xy}}\right)$ yang diperoleh sebesar 0,748. Berdasarkan tabel interpretasi koefisien korelasi dapat disimpulkan bahwa hubungan antara aktivitas belajar mandiri dengan hasil belajar Rangkaian Listrik memiliki hubungan yang kuat.

\section{Uji Signifikansi Koefisien Korelasi}

Berdasarkan hasil perhitungan didapatkan $t_{\text {hitung }}$ sebesar 7,89 sedangkan $t_{\text {tabel }}$ sebesar 2,01, karena $t_{\text {hitung }}>t_{\text {tabel }}$ maka $\mathrm{H}_{\mathrm{o}}$ ditolak, sehingga dapat disimpulkan bahwa terjadi korelasi yang signifikan antara aktivitas belajar mandiri dengan hasil belajar.

\section{Uji Koefisien Determinasi}

Koefisien determinasi $\mathrm{KD}=\mathrm{r}_{\mathrm{xy}}{ }^{2} \mathrm{x} 100 \%=$ $(0,748)^{2} \times 100 \%=55,94 \%$. Hal ini berarti hasil belajar Rangkaian Listrik ditentukan oleh aktivitas belajar mandiri sebesar 55,94\% .

\section{Pembahasan}

Berdasarkan hasil perhitungan yang telah dikemukakan di atas, diketahui terdapat hubungan yang positif dan signifikan antara aktivitas belajar mandiri dengan hasil belajar Rangkaian Listrik siswa SMK Negeri 26 Jakarta. Hasil ini menunjukan bahwa semakin sering siswa melakukan aktivitas belajar mandiri, maka hasil belajar yang diperoleh akan semakin baik. Sebaliknya, siswa yang jarang melakukan aktivitas belajar mandiri menyebabkan rendahnya hasil belajar. Namun aktivitas belajar mandiri bukanlah satu-satunya faktor yang berhubungan dengan hasil belajar Rangkain Listrik, masih terdapat faktor lain seperti minat, bakat, suasana rumah, kompetensi guru dan sebagainya yang berhubungan dengan hasil belajar Rangkaian Listrik. Hasil penelitian ini sesuai dengan teori 
yang dikemukakan oleh Abdul Haris (2013) yang berpendapat bahwa siswa yang sering melakukan aktivitas belajar mandiri akan mampu mencapai hasil belajar yang tinggi. Sebaliknya, siswa yang jarang melakukan aktivitas belajar mandiri akan mencapai hasil belajar yang rendah.

Siswa yang masuk dalam kategori aktivitas belajar mandiri sangat tinggi dan memperoleh hasil belajar tinggi berjumlah 10 siswa. Siswa yang masuk dalam kategori aktivitas belajar mandiri tinggi dan memperoleh hasil belajar tinggi berjumlah 13 siswa. Siswa yang masuk dalam kategori aktivitas belajar mandiri cukup tinggi dan memperoleh hasil belajar tinggi berjumlah 14 siswa. Siswa yang masuk dalam kategori aktivitas belajar mandiri rendah dan memperoleh hasil belajar rendah berjumlah 8 siswa. Siswa yang masuk dalam kategori aktivitas belajar mandiri sangat rendah dan memperoleh hasil belajar rendah berjumlah 2 siswa. Selain itu, dapat diketahui bahwa terdapat data 4 siswa yang mempunyai aktivitas belajar mandiri cukup tinggi, namun memperoleh hasil belajar yang rendah, sehingga pada penelitian ini, peneliti melakukan wawancara kepada orang tua siswa untuk mengkonfirmasi data aktivitas belajar mandiri yang diperoleh.

Peneliti melakukan wawancara kepada 22 orang tua siswa, pengambilan sampel untuk wawancara dilakukan secara acak dengan detail sebagai berikut: 1) Kategori aktivitas belajar mandiri sangat tinggi berjumlah 6 responden orang tua yang diwawancarai. 2) Kategori aktivitas belajar mandiri tinggi berjumlah 4 responden orang tua yang diwawancarai. 3) Kategori aktivitas belajar mandiri cukup tinggi berjumlah 7 responden orang tua yang diwawancarai. 4) Kategori aktivitas belajar mandiri rendah berjumlah 3 responden orang tua yang diwawancarai. 5) kategori aktivitas belajar sangat rendah berjumlah 2 responden orang tua yang diwawancarai.

Berdasarkan hasil pencocokan jawaban antara jawaban angket yang diisi siswa dengan jawaban wawancara orang tua siswa, didapatkan hasil bahwa terdapat perbedaan jawaban antara jawaban orang tua dengan angket yang diisi siswa yaitu 4 siswa pada kategori aktivitas belajar mandiri cukup tinggi, setelah dilakukan konfirmasi data ke orang tua siswa yang bersangkutan ternyata 4 siswa tersebut jarang belajar. Perbedaan jawaban juga terjadi pada kategori aktivitas belajar mandiri sangat tinggi, setelah dilakukan konfirmasi data ke orang tua didapatkan hasil bahwa pada kategori tersebut terdapat 2 siswa yang jarang belajar. Berdasarkan hasil pencocokan jawaban antara jawaban wawancara orang tua dengan jawaban angket yang diisi siswa didapatkan hasil bahwa terdapat perbedaan jawaban antara jawaban wawancara orang tua dengan jawaban angket yang diisi siswa yaitu sekitar $27 \%$. Perbedaan jawaban ini terjadi karena faktor pengaruh lainnya di luar variabel yang diteliti. Hasil wawancara yang dilakukan tidak mempengaruhi hasil penelitian ini.

\section{KESIMPULAN DAN SARAN}

\section{Kesimpulan}

1) Berdasarkan pengategorian data aktivitas belajar mandiri, dengan nilai rata rata yang diperoleh yaitu 94,35, maka aktivitas belajar mandiri siswa kelas X SMKN 26 Jakarta masuk ke dalam kategori cukup tinggi

2) Terdapat hubungan yang positif dan signifikan antara aktivitas belajar mandiri dengan hasil belajar Rangkaian Listrik.

\section{Saran}

1) Guna mendapatkan hasil belajar yang lebih tinggi maka dapat dilakukan dengan menerapkan metode peningkatan aktivitas belajar mandiri, contohnya yaitu dengan cara pemberian tugas berupa merangkum materi pelajaran, mencari fenomena Rangkaian Listrik diluar lingkungan sekolah, mencari bahan di perpustakaan, dan sebagainya.

2) Perlu dilakukan penelitian lebih lanjut yang berkaitan dengan aktivitas belajar mandiri dengan hasil belajar Rangkaian Listrik, karena pada penelitian ini hanya diketahui hubungan kedua variabel tersebut melalui pengisian kuesioner aktivitas belajar mandiri dan tes hasil belajar Rangkaian Listrik, tetapi pada penelitian ini tidak melihat konsistensi siswa dalam melakukan aktivitas belajar mandiri dengan cara melakukan pengontrolan secara berkala terhadap tugas dan soal latihan yang dikerjakan oleh siswa selama satu semester atau satu tahun. 


\section{DAFTAR PUSTAKA}

Aunurrahman. (2009). Belajar dan Pembelajaran. Bandung : Alfabeta.

Darjad, Ajub. (2009). Buku Ajar Rangkaian Listrik I. Semarang.

Destyari, Fidelia. 2016. Hubungan Kemandirian Belajar dan Fasilitas Belajar dengan Hasil Belajar Fisika Kelas XI IPA Semester 2 SMA Pius Bakti Utama Purworejo Tahun Ajaran 2015/2016 [skripsi]. Yogyakarta: Fakultas Keguruan dan Ilmu Pendidikan, Universitas Sanata Dharma.

Djamarah, Syaiful Bahri. (2008). Rahasia Sukses Belajar. Jakarta : Rineka Cipta.

Elis\&Rusdiana. (2015). Evaluasi Pembelajaran. Bandung : CV Pustaka Setia.

Febrina, Nuansa Ayu\&Isroah. (2012). Peningkatan Aktivitas Belajar Akuntansi Melalui Implementasi Model Pembelajaran Kooperatif Tipe Student Teams Achievement Division (STAD) Pada Siswa Kelas X AK 3 Program Keahlian Akuntansi SMK Batik Perbaik Purworejo Tahun Ajaran 2011/2012. Jurnal Pendidikan Akuntansi Indonesia, Vol. X, No. 2.

Hamdani. (2011). Strategi Belajar Mengajar. Bandung : Pustaka Setia.

Hanafiah, Nanang. \& Cucu Suhana. (2009). Konsep Strategi Pembelajaran. Bandung : PT Refika Aditama.

Haris, Abdul. (2013). Evaluasi Pembelajaran. Yogyakarta : Multi Pressindo.

Hayt, William (2015). Rangkaian Listrik. Jakarta : Erlangga.

Kementrian Pendidikan dan Kebudayaan Pusat Pengembangan dan Pemberdayaan Pendidik dan Tenaga Kependidikan Bidang Mesin dan Teknik Industri. 2015. Modul Dasar dan Pengukuran Listrik 2.

Kementrian Pendidikan dan Kebudayaan Republik Indonesia. (2013). Ebook Dasar dan Pengukuran Listrik Semester 2.

M.Thobroni. (2015). Belajar dan Pembelajaran Teori dan Praktik. Yogyakarta : Ar-Ruzz Media.

Purwanto. (2011). Evaluasi Hasil Belajar. Yogyakarta : Pustaka Belajar.

Rohani, Ahmad. (2004). Pengelolaan Pengajaran. Jakarta : PT Rineka Cipta.
Rosyidah. 2010. Hubungan Antara Kemandirian Belajar dengan Hasil Belajar Matematika pada Siswa MTSN Parung-Bogor [skripsi]. Jakarta:Fakultas Ilmu Tarbiyah dan Keguruan, Universitas Islam Negeri Syarif Hidayatullah Jakarta.

Rusman. (2016). Model Model Pembelajaran. Jakarta : Rajawali Pers.

Sardirman. (2006). Interaksi \& Motivasi Belajar Mengajar. Jakarta : PT Raja Grafindo Persada. Slameto. (2003). Belajar dan Faktor Faktor yang Mempengaruhinya. Jakarta : PT Rineka Cipta.

Sudijono, Anas. (2012). Pengantar Evaluasi Pendidikan. Jakarta : PT Raja Grafindo Persada.

Sudjana, Nana. (2009). Penilaian Hasil Proses Belajar Mengajar. Bandung : PT Rosadakarya.

Sugiyono. (2011). Metode Penelitian Kuantitatif Kualitatif dan R\&D. Bandung : CV. Alfabeta.

Sugiyono. (2007). Statistika untuk Penelitian. Bandung : CV. Alfabeta.

Sumardiono. (2013). Pembelajar Mandiri. Rumah Inspirasi \& Bentang Ilmu.

Siregar, Rahmat. 2015. Hubungan Antara Aktivitas Belajar Siswa dan Kemandirian Belajar dengan Hasil Belajar Mengelas Siswa Kelas XII Program Keahlian Teknik Pengelasan SMKN 4 Medan [skripsi]. Medan: Fakultas Teknik, Universitas Negeri Medan.

Trisiana, Anita. (2014). Optimalisasi Belajar Mandiri Tata Pamong (Tinjauan Kritis dan Pengembangan Terhadap Peningkatan Kualitas Sumber Daya Manusia yang Berkarakter). Jurnal Widya Wacana, Vol. 9, No. 2.

UU RI Nomor 20 Tahun 2003

Wahab, Rohmalina. (2015). Psikologi Belajar. Jakarta : Rajawali Pers.

Yudana Putra, Made dkk. (2015). Hubungan Antara Aktivitas Belajar dan Disiplin Belajar Terhadap Hasil Belajar TIK Siswa SMK Pariwisata Triatmajaya. Kumpulan Artikel Mahasiswa Pendidikan Teknik Informatika (KARMAPATI), Vol. 4, No. 4. 